\title{
A model of endemic coronavirus infections
}

\author{
David S. Huen*1 \\ ${ }^{1}$ Retired, Currently unaffiliated
}

\begin{abstract}
This work proposes that epidemiological features of both endemic coronaviruses and the recent highly pathogenic outbreak coronaviruses can be combined within an integrated framework. In this framework, mortality amongst those infected for the first time is mostly amongst the old but survivors acquire fatal infection immunity (FII). Subjects with FII can subsequently be infected and infect others without suffering significant mortality. Under these conditions, coronaviruses induce endemic infections that elicit FII in individuals during childhood when the risk of mortality is low and maintain it throughout their lifetime, thereby protecting the population against the worst effects of infection.

A multi-compartment ODE model was constructed to explore the implications of this proposal on the evolution of a zoonosis sharing properties of both SARS-CoV-2 and endemic coronaviruses. The results show that mortality has two components, the first incurred during transition to endemicity and the other is exacted on a continuing basis. The relative contribution of each depends on the longevity of the FII state. In particular, a one-time vaccination of the older subpopulation is sufficient to reduce total mortality if FII is long-lived. The effect of a regular vaccination was also examined when FII was shorter lived. Herd immunity was not achieved.

The validity of this proposal with regard to Covid-19 depends on whether reinfection with SARS-CoV2 behaves in the manner expected of FII. If it does, then certain considerations apply to how Covid-19 is to be managed and how vaccine choice could influence that.
\end{abstract}

\section{Introduction}

Human endemic coronaviruses (ECoV) comprise four coronaviruses (229E, HKU1, NL63 and OC43) of minor clinical importance (reviewed in Ogimi et al, 2020). They are responsible for a range of upper respiratory tract infections, infecting most humans from an early age and throughout life (Zhou et al, 2013; Ogimi et al, 2020; Dijkman et al, 2012; Huynh et al, 2012). Infections can be asymptomatic (Prill et al, 2012; Walsh et al, 2013; Morikawa et al, 2015). Phylogenetic evidence suggests zoonotic origins for NL63 (from bats, 11901449; Fouchier et al 2004; Huynh et al, 2012), 229E (from bats, 1686-1890; Pfefferle et al, 2009) and OC43 (from cows, 1890s; Vijgen et al 2005). While their clinical presentation is similar, they differ in receptor use, with OC43 and HKU1 targeting 9-O-acetylated sialic acid moieties on surface proteins (Hulswit et al, 2019), 229E targeting aminopeptidase N and NL63 targeting ACE2 (Fouchier et al, 2004).

The ubiquity of ECoV infections suggests ECoV regularly reinfect humans and antibody titre evidence exists demonstrating this (Eldridge et al, 2020). Being of minor clinical significance, the immunology of ECoV infection has been neglected. While antibody titres decline soon after infection, reinfection can and does occur while significant serum antibody titres still persist (Callow et al, 2010; Eldridge et al, 2020). Mucosal antibody titres are likely to be more important than serum antibody titres in preventing reinfection: while the latter were readily detected in older adults, the mucosal wash IgA was only detected in a minority (Gorse et al, 2010). It is not known how ECoV infections are immunologically resolved and while innate and cell-mediated immunity can be expected to play key roles, their role has yet to be investigated.

Understandably, the emergent highly pathogenic coronaviruses responsible for zoonoses over the last two decades have received more attention. As with ECoVs, SARS antibody titres declined after infection (Ho

*Corresponding author: david.s.huen@gmail.com 
It is made available under a CC-BY-NC 4.0 International license .

et al, 2005; Mo et al, 2006). Covid-19 is too new a disease to provide a long observational baseline but the balance of evidence suggests declining serum antibody titres too (Ward et al, 2020; Long et al, 2020; Seow et al, 2020). In contrast, $\mathrm{T}$ cell immunity appears to be sustained long term, with responses detected up to 17 years later with SARS ( $\mathrm{Ng}$ et al, 2016; Le Bert et al, 2020). Strong T cell responses were also elicited by SARS-CoV-2 (hereafter referred to as SARS-2), the causative agent of Covid-19, in both mild and severe cases (Le Bert et al, 2020; Braun et al, 2020; Peng et al, 2020; Sekine et al, 2020) and the immunological differences between these outcomes is now emerging (Laing et al, 2020). Surprisingly, T cell responses to SARS-2 targets were discovered in uninfected controls in some of these studies but not others (Le Bert et al, 2020; Braun et al, 2020; Nelde et al, 2020; Bacher et al, 2020; Peng et al, 2020). These T cells have been attributed to cross-reactive $\mathrm{T}$ cells and the conflicting results to technical differences between studies. However, those identified in one study have been shown to be of low avidity and may the authors propose they are related to age and detrimental to disease outcome (Nelde et al, 2020). Even severe coronavirus infections like SARS and Covid-19 can have an asymptomatic component (Lee et al 2003; Wilder-Smith et al 2005; Kronbichler et al, 2020).

A distinctive feature of SARS, MERS and Covid-19 is that mortality is strongly linked to old age and comorbidities (Chan-Yeung and Xu, 2003; Mizumoto et al, 2015; Park et al, 2018; Ghisolfi et al, 2020). The young are largely spared when infected. Recent work demonstrated that defects in the the innate immunity pathway were associated with severe Covid-19 indicating its importance in controlling SARS-2 (Zhang et al, 2020) and declining innate immunity is a prominent feature of the aging immune system (Fulop et al, 2013; Montgomery and Shaw, 2015; Boe et al, 2017).

I suggest that the characteristics of $\mathrm{ECoV}$ and the more recent highly pathogenic viruses can be married within a model based on:-

- A S(usceptible) state where mortality during infection increases with age: non-immune subjects will be in this state.

- A V(iable) infectible state with negligible mortality. The V state is persistent, possibly lifelong.

- On surviving an infection, all subjects are briefly resistant to reinfection then enter the V state.

The existence of the S state cannot be readily demonstrated with ECoVs as they will have infected the entire population during their youth when S state mortality is expected to be negligible. Conversely, the mortality profiles of SARS and Covid-19 are very much what is expected of the S state. Also, the recent coronavirus zoonoses show varying mortality with Covid-19 < SARS $<$ MERS. ECoV are also capable of fatal lower respiratory tract infections so they cannot be precluded a priori from also possessing age-dependent $\mathrm{S}$ state mortality profiles (Gorini da Veiga, et al, 2020). The OC43 zoonosis has been suggested as the true cause of the Russian flu pandemic of the 1890s (Vijgen et al, 2005).

In contrast, ECoVs clearly show $\mathrm{V}$ state behaviour with frequent reinfections separated by short periods of resistance to reinfection. The severity of MERS and SARS drove strenous efforts that eradicated those viruses before reinfection was observed. Covid-19 is too new to have observed significant levels of reinfection. Of the five known cases, none have been fatal. SARS immunology showed antibody responses to be shortlived but $\mathrm{T}$ cell responses were maintained over many years. This would be consistent with the $\mathrm{V}$ state characteristics if antibody responses correlated with protection from reinfection and $\mathrm{T}$ cell responses with protection from fatal infection.

Within this model, ECoV infections are endemic and maintained in the community by the absence of long-term immunity to reinfection. Long term herd immunity cannot be attained under these conditions. Humans are first infected and immunologically primed as children when they are least likely to exhibit fatal outcomes. If fatal infection immunity is lifelong, circulating infections are responsible for its establishment amongst neonates. If not, it plays an additional role in maintaining FII throughout the population such that completely losing immunity and returning to the $\mathrm{S}$ state is uncommon and fatal infection is therefore an rare outcome. It is noted that the recent coronavirus zoonoses originated from bats and they have a dense social structure ideally suited to maintaining high rates of infection throughout their lifespan. It is not therefore necessary to invoke unique physiological characteristics to explain why they can sustain high levels of coronavirus infections without fatality if bat viruses have ECoV characteristics. 
It is made available under a CC-BY-NC 4.0 International license .

Again, this proposal predicts that when a new ECoV zoonosis occurs, fatalities only occur amongst the non-immune part of population and then, mostly amongst the old. Thereafter, a lower rate of mortality is experienced, that rate being dependent on how fast FII is lost. With lifelong FII, the maximum death toll that can be suffered from such a zoonosis is that obtained by applying the age- and sex-specific infection fatality rate (IFR) profile to the demographic profile of that population. For example, for the UK, IFR estimates range up to $0.9 \%$ and a maximum potential mortality is 600 thousand persons (Ward et al, 2020). By way of comparison, there are around 600 thousand deaths annually in the UK so if Covid-19 induces lifelong FII, its theoretical worst case outcome is equivalent to the deaths that can be expected in a year although that would certainly exceeded in practice when critical care facilities are overwhelmed. Since Covid19 deaths are mainly amongst the old, this will also result in depressed excess deaths in the next few years. Fatalities from ECoV zoonosis are effectively self-limited if FII is long-lasting.

There are also implications for control measures. Since circulating infection is a key protective aspect of $\mathrm{ECoV}$ infection, control measures need to lower mortality without hindering the transition to endemicity.

This study modelled the behaviour of ECoV infections and interventions in the transition towards endemicity.

\section{Model Structure}

The model is a multi-compartment ODE model (figure 1). The S state has already been described. The $\mathrm{R}$ (ecovered) state represents a short period of immunity to reinfection enjoyed after recovering from an infection. Two states of infection are specified. The potentially $\mathrm{F}$ (atal) state represents the infection of a naive subject and it resolves by transiting to either the $\mathrm{R}$ state or the $\mathrm{D}$ (ead) state, the partition between the two being determined by an age- and sex-dependent infection fatality rate (IFR). The alternative infected $\mathrm{Y}$ state represents reinfection of an already immune host and only resolves non-fatally to the $\mathrm{R}$ state.

The V state represents those possessing FII, who are infectible but will not be killed by the virus. If FII is not lifelong, subjects exit the V state to return to the S state.

Each state has an internal age profile of 90 year-wide bins for each of the sexes. Aging was modelled in all states that represent living subjects to permit long-term evolution of the model.

Rate coefficients are indicated next to the edge that represents that state transition in figure 1.

Further details of the model are available in the Material and Methods.

\section{Results}

\section{Transition to endemicity}

The implications of these ECoV chracteristics was investigated in an contact matrix-based ODE model. A population of 1 million individuals was simulated, setting $R_{0}=2.5$ with recovery from infection as a first-order process with a 6 day half-life. Resistance to reinfection was lost with a 1 year half-life to model the interval between infections experienced with ECoVs. The simulations were initially performed assuming lifelong FII $(\kappa=0)$ and varied later.

Two populations were initially modelled with England+Wales as the base case and Singapore as the alternate case, using age, sex and mortality profiles and contact matrices specific to each. As the long-term behaviour of the endemic was of interest, the model also incorporated aging of the population. The birth rate was continuously adjusted to maintain a constant population. The two populations represent economically welldeveloped communities at different stages in the demographic transition with Singapore being at an earlier stage. Consequently, its population structure is younger than that expected from its age- and sex-specific mortality rates and its birth rates in the population rose later in simulation to balance increased deaths from aging. The infection fatality ratio profile used in the simulation was the High Income Country set for Covid-19 reported by Ghisolfi et al, 2020.

All simulations were seeded with an infected, 20 year old male in the F state. 
It is made available under a CC-BY-NC 4.0 International license .

The base case examined the natural evolution of a zoonosis over a 50 year span where the seeded population was initially in the non-immune $\mathrm{S}$ state (figure $2(\mathrm{a})$ ).

Both populations showed qualitatively similar behaviour (figure 2).

It can expected that without a lifelong uninfectible state, infection would spread throughout the population and the surviving population will be refractory to fatal infection thereafter, new births being immunized by circulating infection. However, following an initially rapid spread, progress thereafter was slower and around a half decade was required to converge towards the same equilibrium. This can be attributed to a third of the population being in the short-term uninfectible $\mathrm{R}$ state and subsequently temporarily hindering the spread of infection. This is also observed with deaths continuing to rise for many years (figure 2(b)). Deaths were higher in England+Wales than Singapore, as expected since the former is an older population (figure $2(\mathrm{~b}))$.

It was noted that the S state did not decline to zero with time and that appeared to contradict the earlier claim of complete infection (figure 2(a)). To explore this further, a modified dual model was built in which every state was duplicated and the paired submodels were linked via infection. A cohort could therefore be transferred to and segregated within the secondary submodel and its fate tracked through an entire lifetime. When births and the initial cohort were segregated, it can be seen that the subjects in S state initially were completely depleted by infection and the subsequent occupants of the $\mathrm{S}$ state were derived from new births (figure 2(c)).

From the foregoing, fatalities would occur only amongst the initial cohort with lifelong FII. A crude estimate of that mortality can be obtained by applying the age- and sex-specific IFR to that cohort assuming that they would be promptly infected. Using the segregated model, disease mortality of cohorts of each 10 year age group were tracked across their entire lifetimes and compared against the IFR-derived estimates (tables 1 and 2). The results closely matched expectations at most age categories.

The median time to fatal infection (MTFI) and lifetime IFR (LIFR) were also estimated for the base case (tables 3 and 4). With lifelong FII, the majority of fatalities occur in the first wave of infections (table 3, 2nd column). With finite FII halflives, subjects occasionally return to the S state over their remaining years, where they were exposed to a rising risk of fatal infection. The MTFI for age groups indicate that the majority of virus-caused deaths occurred after they entered their late 70s (table 3). The LIFR also show virus deaths rising with both initial age and $\kappa$ (i.e. shorter FII halflives). The former can be explained by older age groups having higher risks of mortality during their initial, unprotected infection. The young will have FII by being infected while their risk of FII was low. The risk of loss of FII increases with $\kappa$, eventually exposing a fraction of those cohorts to virus mortality in their old age.

This model has a force of infection (FOI) that is common to to all subjects within an age-group, that is, the per-person rate of infection is the same for all within that age group. The FOI for the ath age group is described by

$$
(\mathrm{FOI})_{a}=\beta \sum_{\alpha} \mu_{\alpha, a} \frac{I_{\alpha}}{N_{\alpha}}
$$

where $I_{\alpha}$ is the number of infected and $N_{\alpha}$, the size of the $\alpha$ th age group in the population. $\mu_{\alpha, a}$ are terms linking the $a$ th and $\alpha$ th age groups in the contact matrix.

The infection rate for a subpopulation at risk is then just the product of the size of that subpopulation with the appropriate FOI for that age-group. Note that the FOI underwent sharp transients early in the infection that eventually decayed to their equilibrium values (figure 3(a)). The value of FOI can be considered as the average number of infections per person per unit time so its reciprocal is roughly the time between infections for that age group, neglecting time spent in the $R$ state. It was noted that the FOI was lower for both the very young and the very old (figure 3(b)). For the England+Wales model, the $75+$ year year old age group had an FOI of 0.67 which corresponds to an infection every 1.5 years although the average of a year spent in the $R$ state would increase that. This should be adequate to maintain a fair degree of FII at lower $\kappa$ values. The combination of reduced FOI and increased mortality from other sources also negated some of the effect of increased IFR amongst the 80+ age group. 
It is made available under a CC-BY-NC 4.0 International license .

\section{Limited duration immunity}

The foregoing analysis assumed lifelong immunity to fatal reinfection. The effects of this immunity being long-lasting but not lifelong is now examined. A particular concern is that the reinfection could be too infrequent to maintain fatal infection immunity (FII).

The loss of FII is represented in the model by a $\mathrm{V} \rightarrow \mathrm{S}$ first-order decay that is parameterized by $\kappa$. Values ranging from $\kappa$ between 0.025-0.2 were examined, which correspond to $\mathrm{V}$ decay half-lives of 27.7 years down to 3.5 years. Non-zero values of $\kappa$ had the effect of increasing the occupancy of the S state associated with mortality and decreasing that in the $\mathrm{V}$ state which is not subject to fatal infection figure 4(a). However, while the $\mathrm{V} \rightarrow \mathrm{S}$ transfer was not age-specific, age-specific variations in contacts resulted in biased age distributions for the $\mathrm{S}$ and $\mathrm{V}$ states. The mid-range age groups were reinfected and retained in states within the non-fatal infection loop $(\mathrm{R}, \mathrm{V}$ and $\mathrm{Y})$ by their higher numbers of contacts while the young and old were preferentially lost (figures 4(b); see figure legend for explanation of spike at age 50). The old were swept into the S state with concomitant loss of FII wherein they were preferentially retained for the same reason (figure 4(c)). The young started in the $\mathrm{S}$ state but were steadily removed by infection from the $\mathrm{S}$ state to the $\mathrm{V}$ state (figure $4(\mathrm{c})$ ). In contrast, the limited residual life expectancy of the old resulted in other causes of mortality claiming a proportion of those in the S state before they could succumb to the virus.

Mortality with limited term FII can be characterised by an initial, one-off transitional mortality (figure 5(a)) followed by a transition to a long term, equilibrium endemic mortality rate that was dependent on $\kappa$ (figure $5(\mathrm{~b})$ ). Whereas the endemic mortality rate was zero with lifelong FII, it rose with increasing values of $\kappa$ as decay of FII exposed increasing numbers of subjects to fatal reinfection.

The initial death toll was large, irrespective of $\kappa$. When the 2-year death toll is used as a proxy for the common transitional mortality, estimates ranged between 7753 and 7996 for the England+Wales model. Equivalent figures of 5574 and 5767 were obtained for the Singapore model.

Without lifelong FII, the endemic mortality rate was rose rapidly with $\kappa$ and was substantial at high $\kappa$ (tables 5 and 6$)$. At the highest value modelled $(\kappa=0.2)$, annual mortality was 864 and 1057 for the England+Wales and Singapore models respectively (tables 5 and 6), corresponding to $6.69 \%$ and $7.94 \%$ of total mortality respectively toward the end of the simulation. As a point of reference, influenza and pneumonia constitute $5 \%$ of deaths in England and Wales with an ongoing vaccination programme. However, it should be noted that other causes mortality rose from around 8400 to nearly 13000 as the population aged over the 50 year simulation period but since both the mortality from modelled outbreak and influenza/pneumonia arises from the same elderly population, this comparison may still be valid. Whether the new outbreak will contribute additively to influenza deaths is beyond the scope of this work but a novel ECoV and influenza will draw many of their fatalities from the same pool of the elderly.

\section{Vaccination}

The use of vaccination to reduce the death toll during the the transition to endemicity was studied. It was reasoned that accelerating the establishment of FII by a single vaccination could reduce mortality during the transition to endemicity even if no subsequent vaccinations were administered since circulating infection would maintain protection thereafter. This was modelled by moving half of the initial population above either the age of 20 or 60 from the $\mathrm{S}$ state to the $\mathrm{R}$ state and examining outcomes with either lifelong FII or with $0.025 \leq \kappa \leq 0.2$. The difference between the transition mortality in the base case and that of the intervention case is then an estimate of the lives saved by that intervention. The results can be seen in Tables 5 and 6 .

With lifelong FII, vaccinating $50 \%$ of over-60s reduced deaths by $47.5 \%$ and $47 \%$ in the England+Wales and Singapore models respectively. (tables $1,2,5$ and 6 ). The small shortfall arose from under-60s being fatally infected for the first time as they aged as is apparent when deaths with the over-60s vaccination is compared against that from vaccinating over-20s. That comparison also demonstrates the diminishing returns from expanding the scope of vaccination to younger ages as a means of reducing transitional mortality. 
It is made available under a CC-BY-NC 4.0 International license .

With shorter FII half-lives, the control of endemic immunity becomes increasingly important but requires periodic vaccination programmes. A crude attempt was made to model periodic vaccination by moving a fraction of the living population each year to the $\mathrm{R}$ state. Two rates were examined, a effective vaccination rate of $20 \%$ and $40 \%$ of the over-60s population per year and the impact of these interventions on endemic mortality was examined (tables 5 and 6 ). As expected, the protection improved with vaccination rate and fell when the FII state was shorter-lived (i.e. higher $\kappa$ ). The vaccination gains appear poor: vaccinating $40 \%$ of the $>60$ year olds annually would be expected to yield much more than a $40 \%$ gain when FII is longer-lived. This is a consequence of the vaccination being inefficiently targeted at many that were still immune. Vaccination on a periodic basis would have targeted those more likely to be losing FII but ODE modelling is ill-suited to this. Better analysis of vaccination programme details will require the use of other modelling approaches.

\section{Discussion}

This study proposes that ECoV and more recent pathogenic coronaviruses share a set of immunological properties that have not been fully observed in either group of viruses. This proposal can be modelled to generate falsifiable predictions of outbreak behaviour.

A central feature of this proposal is that immunity acquired safely when young, is maintained throughout life by reinfection, protects the subject from death when they reach the age when they would otherwise be vulnerable. To this end, an ODE model has been constructed to model long-term evolution of ECoV type outbreaks incorporating aging of the population. Contact matrices incorporate key interactions between the different age groups.

Simulations using this model showed two components to virus mortality. The first component occurs between the start of the outbreak and the establishment of an endemic steady state. Therafter, the population suffers from the ongoing endemic mortality rate. Decreasing durability of FII shifts the mortality away from a initial quantum towards an ongoing death toll.

The immediate utility of this proposal lies in the predictions that emerge from this model if it should be applicable to Covid-19. That can only be known if the epidemiology of reinfection of SARS-2 is better understood. Indeed, elucidating that is crucial to the management of Covid-19. With regard to this proposal, the mortality and morbidity experienced in reinfection will determine whether FII exists. The model in its current simple form postulates that the FII state is fully infectious and this may also need to be modified in the light of experience. The best course of action remains the deployment of a vaccine if one is available irrespective of whether this proposal holds true. If subsequent data shows an infectible FII state exists, then considerations derived from this model may come into play and these are now discussed.

If the FII state is sufficiently long-lived and has an acceptable level of morbidity on reinfection, there is the option of letting the outbreak evolve towards endemicity. The role of the vaccine is the suppression of transition mortality and assuming that the vaccine used establishes an immune state similar to that of FII, all this would require is a single application of the vaccination programme covering the entire population. Circulating infection will immunize neonates and maintain FII thereafter.

If the FII state is shorter-lived, continued vaccination will rest on whether the endemic mortality rate and morbidity of the endemic state are acceptable. A programme targeted at the elderly and those with comorbidities only may be adequate.

The properties of the vaccine also matter. If a vaccine conferred an unexpectedly long immunity against reinfection, then that vaccine could establish herd immunity and also be the basis of an global eradication effort. However, few vaccination programmes achieve total coverage and if this route is taken, significant fractions of the population may be unvaccinated and they remain vulnerable to fatal infection if vaccination is discontinued and the virus reintroduced from elsewhere. If immunity elicited by this supra-natural vaccine decays to the $\mathrm{V}$ state, the programme could still be discontinued at a later stage and circulating infection restablished to protect the population. However, circulating infection must be established before immunity wanes further to put the population back to the immunologically naive and fatally vulnerable S state. 


\section{Materials and Methods}

\section{Software}

Simulations were performed using R 3.6.1 and RStudio 1.3.1093 (R Core Team, 2019; RStudio Team, 2016).

\section{States}

States are consists of a vector of 180 elements, 90 for each sex. The elements represent counts for that sex in 1 year wide age groups up to the age of 90 years.

To avoid clutter, the sex indices have been omitted in the equations shown below.

\section{Demographic data}

England and Wales mortality data for 2019 was obtained from NOMIS, downloaded on 19/10/2020. England and Wales population structure for 2019 was obtained from NOMIS, downloaded on 19/10/2020. NOMIS is at https://www.nomisweb.co.uk/

Singapore mortality data for 2018 was obtained from Singstat. Singapore population structure for 2018 was obtained from Singstat. Singstat is at https://www.singstat.gov.sg/

\section{IFR data}

Covid-19 IFR data was obtained from Ghisolfi et al, 2020. However, the 10 year wide bands it was provided in resulted in discontinuous jumps in the age profiles of many metrics. Also, the death rate changes very significantly across that 10 year band. This issue was addressed by fitting an exponential relationship to data form ages above 50 as the IFR takes very small values below that and the quality of fit there is inconsequential to the results of simulations.

A final issue is that the final age bin for states is for age $\geq 89$ and an FOI should be specified on the same basis. In this simulation, the effective age of that final bin was arbitrarily specified as 95 to account for that.

\section{Contact matrix}

Contact matrices were obtained from Prem et al, 2017.

The contact matrices are defined with ages grouped into 5 year bins spanning 0-80 years of age. Also, they are not sex-specific. The contract matrices were block-expanded and reweighted to cover the 0-90 age range used in this simulation.

It was assumed that contact matrices did not change significantly over the duration of the simulation.

\section{Model equations}

$$
\begin{gathered}
(\mathrm{FOI})_{a}=\beta \sum_{\alpha} \mu_{\alpha, a} \frac{I_{\alpha}}{N_{\alpha}} \\
\frac{d S_{a}}{d t}=-(\mathrm{FOI})_{a} S_{a}+\kappa V_{a} \\
\frac{d F_{a}}{d t}=(\mathrm{FOI})_{a} S_{a}-\gamma F_{a}
\end{gathered}
$$




$$
\begin{gathered}
\frac{d R_{a}}{d t}=\gamma\left(1-(\mathrm{IFR})_{a}\right) F_{a}+\gamma Y_{a}-\delta R_{a} \\
\frac{d V_{a}}{d t}=\delta R_{a}-(\mathrm{FOI})_{a} V_{a} \\
\frac{d Y_{a}}{d t}=(\mathrm{FOI})_{a} V_{a}-\gamma Y_{a} \\
\frac{d D_{a}}{d t}=\gamma(\mathrm{IFR})_{a} F_{a} \\
I=F+V \\
N=S+F+R+V+Y
\end{gathered}
$$

\section{Aging}

Aging for the S,F,R and Y states was implemented by annually shifting the contents of age bins in the state vectors up one year. The final age $\geq 79$ bin is not shifted but also accumulates the contents of the the age 78 bin at each update.

A consequence of stepped aging is periodic jitter in model parameters. Some rate variables were averaged over 40 periods ( 2 years) in tables to reduce the influence of this.

\section{Calibration of beta}

The contact matrix plays a central role in determining the dynamics of the model since it describes the potentially infectious contacts between age groups. It has been suggested that there is an age-dependent susceptibility to infection and the contact matrix was modified to reflect the reduced susceptibilities amongst the young as proposed in Davies et al, 2020.

When the simulations for different populations are to be compared, a decision has to be made on what is to be held invariant between the populations. In this case, either $R_{0}$ or $\beta$ could be fixed. There did not appear to be strong grounds for holding $R_{0}$ constant since the social connectedness of populations, and therefore $R_{0}$, can be expected to differ. $\beta$ is associated with the probability of infection for a given contact rate and may perhaps be more of an intrinsic feature than $R_{0}$ although cultural practices may be expected to influence the risk of infection on social contact too. A decision was taken to derive the $\beta$ required to achieve $R_{0}=2.5$ in the England+Wales simulation and use the same value of $\beta$ for the Singapore simulation.

The relationship between $\beta$ and $R_{0}$ was established by running simple SIR simulations using a specified contact matrix over a range of $\beta$ values and calculating the associated $R_{0}$ from the asymptotic terminal fraction infected at herd immunity using the final size equation (Heffernan, Smith and Wahl, 2005). The required $\beta$ of 93.5 for $R_{0}=2.5$ in the England+Wales simulation was then obtained by interpolation. This was equivalent to $R_{0}$ being 2.94 in the Singapore case. The raised $R_{0}$ in the latter reflected the higher connectedness of the Singapore population as embedded in the weights of the contact matrix.

\section{Supplementary information}

The RMarkdown script that ran all simulations and generated this manuscript is deposited as supplementary data. 


\section{Acknowledgments}

This study was entirely self-funded.

The use of bibliographic services via the University of Cambridge is gratefully acknowledged.

\section{References}

Al Hammadi AM, Chu DKW, Eltahir YM, Al Hosani F, Al Mulla M, Tarnini W, Hall AJ, Perera APM, Abdelkhalek MM, Peiris JSM, Al Huhairi SS, Poon, LLM (2015) Asymptomatic MERS-CoV Infection in Humans Possibly Linked to Infected Dromedaries Imported from Oman to United Arab Emirates, May 2015. 21: 2197-2200. Emerg. Infect. Dis. http://dx.doi.org/10.3201/eid2112.15113

Bacher P, Rosati E, Esser D, Martini GR, Saggau C, Schiminsky E, Dargvainiene J, Schöder I, Weiters I, Khodamoradi Y, Eberhardt F, Holger N, Sonntagbauer M, Vehreschild MJGT, Conrad C, Tran F, Rosenstiel P, Markewitz R, Wandinger, K, Rybniker J, Kochanek M, Leypoldt F, Cornely OA, Koehler P, Franke A, Scheffold A (2020) Pre-existing T cell memory as a risk factor for severe COVID-19 in the elderly. medRxiv:20188896v1 [Preprint][Cited 27/10/2020] Available from https://www.medrxiv.org/content/ 10.1101/2020.09.15.20188896v1 https://doi.org/10.1101/2020.09.15.20188896

Boe DM, Boule LA, Kovacs EJ (2017) Innate immune responses in the ageing lung. Clin Exp Immunol 187:16-25. doi:10.1111/cei.12881

Braun J, Loyal L, Frentsch M, Wendisch D, Georg P, Kurth F, Hippenstiel S, Dingeldey M, Kruse B, Fauchere F, Baysal E, Mangold M, Henze L, Lauster R, Mall MA, Beyer K, Rohmel J, Voigt S, Schmitz J, Miltenyi S, Demuth I, Muller MA, Hocke A, Witzenrath M, Suttorp N, Kern F, Reimer U, Wenschuh H, Drosten C, Corman VM, Giesecke-Thiel C, Sander LE, Thiel A (2020) SARS-CoV-2-reactive T cells in healthy donors and patients with COVID-19. Nature Early Access. https://doi.org/10.1038/s41586-020-2598-9

Callow KA, Parry HF,Sergeant M, Tyrell DAJ (1990) The time course of the immune response to experimental coronavirus infection in man. Epidemiol. Infect. 105:435-446. doi:10.1017/S0950268800048019

Chan-Yeung M, Xu RH (2003) SARS:Epidemiology. Respirology 8:S9-S14. doi:10.1046/j.1440-1843.2003. 00518.x

Davies NG, Klepac P, Liu Y, Prem K, Jit M, CMMID Covid-19 Working Group, Eggo RM (2020) Agedependent effects in the transmission and control of COVID-19 epidemics. Nature Medicine 26:05-1211. doi:10.1038/s41591-020-0962-9

Dijkman R, Jebbink MF, Gaunt E, Rossen JWA, Templeton KE, Kuijpers TW, van der Hoek L (2012) The dominance of human coronavirus OC43 and NL63 infections in infants. J Clin Virol 53:135-139. doi: 10.1016/j.jcv.2011.11.011

Eldridge AWD, Kaczorowska J, Hoste ACR, Bakker M, Klein M, Loens K, Jebbink MF, Matser A, Kinsella CM, Rueda P, Ieven M, Goosens H, Prins M, Sastre P, Deijs M, van der Hoek L (2020) Seasonal coronavirus protective immunity is short-lasting. Nat. Med. Early access. doi:10.1038/s41591-020-1083-1

Fouchier RAM, Hartwig NG, Bestebroer TM, Niemeyer B, de Jong JC, Simon JH, Osterhaus ADME (2004) A previously undescribed coronavirus associated with respiratory disease in humans. Proc Natl Acad Sci USA 101:6212-6216. doi:10.1073/pnas.0400762101

Fulop T, Larbi A, Pawelec G (2013) Human T cell aging and the impact of persistent viral infections. Front Immunol 4:271. doi:10.3389/fimmu.2013.00271

Ghisolfi S, Almås I, Sandefur JC, von Carnap T, Heitner J, Bold T (2020) Predicted COVID-19 fatality rates based on age, sex, comorbidities and health system capacity. BMJ Global Health 5:e003094. doi: 10.1136/bmjgh-2020-003094

Gorini da Veiga ABG, Martins LG, Riediger I, Mazetto A, Debur M, Gregianini TS (2020) More than just a common cold: Endemic coronaviruses OC43, HKU1, NL63, and 229E associated with severe acute respiratory infection and fatality cases among healthy adults. J Med Virol Early Access. doi:10.1002/jmv.26362 
It is made available under a CC-BY-NC 4.0 International license .

Gorse GJ, Patel GB, Vitale JN, O'Connor TZ (2010) Prevalence of Antibodies to Four Human Coronaviruses Is Lower in Nasal Secretions than in Serum. Clin Vacc Immunol 17:1875-1880. doi:10.1128/CVI.00278-10

Ho MS, Chen WJ, Chen HY, Lin, SF, Wang MC, Di J, Lu YT, Liu CL, Chang SC, Chao CL, Chao CL, King CC, Chiou JM, Su IJ, Yang JY (2005) Neutralizing antibody response and SARS severity. Emerg. Infect. Dis. 11:1730-1737. doi:10.3201/eid1111.040659

Hoffman JM, Smith RJ, Wahl LM (2005) Perspectives on the basic reproduction ratio. J. R. Soc. Interface 2:281-293. doi:10.198/rsif.2005.0042.

Hulswit, RJG, Lang YF, Bakkers MJG, Li WT, Li ZS, Schouten A, Ophorst B, van Kuppeveld FJM, Boons GJ, Bosch BJ, Huizinga EG, de Groot RJ (2019) Human coronaviruses OC43 and HKU1 bind to 9-Oacetylated sialic acids via a conserved receptor-binding site in spike protein domain A. Proc. Natl Acad Sci USA 116:2681-2690. doi:10.1073/pnas.1809667116

Huynh J, Li S, Yount B, Smith A, Sturges L, Olsen JC, Nagel J, Johnson JB, Agnihothram S, Gates JE, Frieman MB, Baric RS, Donaldson EF (2012) Evidence Supporting a Zoonotic Origin of Human Coronavirus Strain NL63. J Virol 86:12816-12825. http://dx.doi.org/10.1128/JVI.00906-12

Kronbichler A, Kresse D, Yoon S, Lee KH, Effenberger M, Shin JI (2020) Asymptomatic patients as a source of COVID-19 infections: A systematic review and meta-analysis. Int J Inf Dis 98:180-186. doi: 10.1016/j.ijid.2020.06.052

Laing AG, Lorenc A, del Barrio ID, Das A, Fish M, Monin L, Munoz-Ruiz M, McKenzie DR, Hayday TS, Francos-Quijorna I, Kamdar S, Joseph M, Davies D, Davis R, Jennings A, Sofra V, Cano F, Greco M, Theodoridis E, Freedman J, Gee S, Chan JNE, Ryan S, Bugallo-Blanco E, Peterson P, Kisand K, Haljasmagi L, Chadli L, Moingeon P, Martinez L, Merrick B, Bisnauthsing K, Brooks K, Ibrahim MAA, Mason J, Gomez FL, Babalola K, Abdul-Jawad S, Cason J, Mant C, Seow J, Graham C, Doores KJ, Di Rosa F, Edgeworth J, Shankar-Hari M, Hayday AC (2020) A dynamic COVID-19 immune signature includes associations with poor prognosis. Nat Med. 26:1623:1635. doi:10.1038/s41591-020-1038-6

Le Bert N, Tan AT, Kunasegaran K, Tham CYL, Hafezi M, Chia A, Chng MHY, Lin MY, Tan N, Linster M, Chia WN, Chen MIC, Wang LF, Ooi EE, Kalimuddin S, Tambyah PA, Low JGH, Tan YJ, Bertoletti A (2020) SARS-CoV-2-specific T cell immunity in cases of COVID-19 and SARS, and uninfected controls. Nature 584:457-462. doi:10.1038/s41586-020-2550-z

Lee HKK, Tso EYK, Chau TN, Tsang OTY, Choi KW, Lai TST (2003) Asymptomatic Severe Acute Respiratory Syndrome-associated Coronavirus Infection. Emerg. Infect. Dis. 9: 1491-1492. doi: 10.3201/eid0911.030401

Long Q, Tang X, Shi Q, Li Q, Deng H, Yuan J, Hu J, Xu W, Zhang Y, Lv F, Su K, Zhang F, Gong J, Wu B, Liu X, Li J, Qiu J, Chen J, Huang A (2020) Clinical and immunological assessment of asymptomatic SARS-CoV-2 infections. Nat Med. 26:1200-1204. https://doi.org/10.1038/s41591-020-0965-6

Mizumoto K, Saitoh M, Chowell G, Miyamatsu Y, Nishiura H (2015) Estimating the risk of Middle East respiratory syndrome (MERS) death during the course of the outbreak in the Republic of Korea, 2015. Int J Inf Dis 39:7-9. http://dx.doi.org/10.1016/j.ijid.2015.08.005

Mo HY, Zeng GQ, Ren XL, Li H, Ke CW, Tan YX, Cai CD, Lai KF, Chen RC, Chan-Yeung M, Zhong NS (2006) Longitudinal profile of antibodies against SARS-coronavirus in SARS patients and their clinical significance Respirology 11: 49-53. doi:10.1111/j.1440-1843.2006.00783.x

Montgomery RR, Shaw AC (2015) Paradoxical changes in innate immunity in aging: recent progress and new directions. J. Leukocyte Biol 98: 937-943. doi:10.1189/jlb.5MR0315-104R

Morikawa S,Hiroi S, Kase T (2015) Detection of respiratory viruses in gargle specimens of healthy children. J Clin Virol 64:9-63. doi:10.1016/j.jcv.2015.01.006

Nelde A, Bilich T, Heitmann JS, Maringer Y, Salih HR, Roerden M, Lubke M, Bauer J, Rieth J, Wacker M, Peter A, Horber S, Traenkle B, Kaiser PD, Rothbauer U, Becker M, Junker D, Krause G, Strengert M, Schneiderhan-Marra N, Templin MF, Joos TO, Kowalewski DJ, Stos-Zweifel V, Fehr M, Rabsteyn A, Mirakaj 
It is made available under a CC-BY-NC 4.0 International license .

V, Karbach J, Jager E, Graf M, Gruber LC, Rachfalski D, Preuss B, Hagelstein I, Marklin M, Bakchoul T, Gouttefangeas C, Kohlbacher O, Klein R, Stevanovic S, Rammensee, HG Walz JS (2020) SARS-CoV2-derived peptides define heterologous and COVID-19-induced $\mathrm{T}$ cell recognition. Nat. Immunol. Early Access. https://doi.org/10.1038/s41590-020-00808-x.

Ng, OW, Chia A, Tan AT, Jadi RS, Leong HN, Bertoletti A, Tan YJ (2016) Memory T cell responses targeting the SARS coronavirus persist up to 11 years post-infection. Vaccine 34:2008-2014. doi:10.1016/j. vaccine.2016.02.063

Ogimi C, Kim, YJ, Martin ET, Huh HJ, Chiu C, Englund JA (2020) What's new with old coronaviruses? J Ped Inf Dis Soc 9:210-7.doi:10.1093/jpids/piaa037

Park J,Jung S,Kim A, Park J (2018) MERS transmission and risk factors: asystematic review. BMC Pub Health 18:574. doi:10.1186/s12889-018-5484-8

Peng YC, Mentzer AJ, Liu GH, Yao X, Yin ZX, Dong DN, Dejnirattisai W, Rostron T, Supasa P, Liu C, Lopez-Camacho C, Slon-Campos J, Zhao YG, Stuart DI, Paesen GC, Grimes JM, Antson AA, Bayfield OW, Hawkins DEDP, Ker, DS, Wang, BB, Turtle L, Subramaniam K, Thomson P, Zhang P, Dold C, Ratcliff J, Simmonds P, de Silva T, Sopp P, Wellington D, Rajapaksa U, Chen YL, Salio M, Napolitani G, Paes W, Borrow P, Semple MG, Baillie JK, Moore S, Openshaw PJM, Ansari MA, Dunachie S, Barnes E, Frater J, Kerr G, Goulder P, Lockett T, Levin R Zhang YH, Jing RH, Ho LP, Cornall RJ, Conlon CP, Klenerman P, Screaton GR, Mongkolsapaya J, McMichael A, Knight JC, Ogg G, Dong T (2020) Broad and strong memory CD4(+)and CD8(+)T cells induced by SARS-CoV-2 in UK convalescent individuals following COVID-19. Nat Immunol 21:1336-1345. doi:https://doi.org/10.1038/s41590-020-0782-6

Pfefferle S, Oppong S, Drexler JF, Gloza-Rausch F, Ipsen A, Seebens A, Muller MA, Annan A, Vallo P, Adu-Sarkodie Y, Kruppa TF, Drosten, C (2009) Distant relatives of severe acute respiratory syndrome coronavirus and close relatives of human coronavirus 229E in bats, Ghana. Emerg. Infect. Dis. 15:13771384. doi:10.3201/eid1509.090224

Prem K, Cook AR, Jit M (2017) Projecting social contact matrices in 152 countries using contact surveys and demographic data. PLoS Comput Biol 13(9): e1005697. https://doi.org/10.1371/journal.pcbi.1005697

Prill MM, Iwane MK, Edwards KM, Williams JV, Weinberg GA, Staat MA, Willby MJ, Talbot HK, Hall CB, Szilagyi PG, Griffin MR, Curns AT, Erdman DD (2012) Human Coronavirus in Young Children Hospitalized for Acute Respiratory Illness and Asymptomatic Controls. Ped Inf Dis J 31:235-240. doi:10.1097/INF. 0b013e $31823 \mathrm{e} 07 \mathrm{fe}$

R Core Team (2019) R: A language and environment for statistical computing. R Foundation for Statistical Computing, Vienna, Austria. https://www.R-project.org/.

RStudio Team (2016) RStudio: Integrated Development Environment for R. RStudio Inc, Boston, MA. http://www.rstudio.com/

Sekine T, Perez-Potti A, Rivera-Ballesteros O, Stralin K, Gorin JB, Olsson A, Llewellyn-Lacey S, Kamal H, Bogdanovic G, Muschiol S, Wullimann DJ, Kammann T, Emgard J, Parrot T, Folkesson E, Rooyackers O, Eriksson LI, Henter JI, Sonnerborg A, Allander T, Albert J, Nielsen M, Klingstrom J, Gredmark-Russ S, Bjorkstrom NK, Sandberg JK, Price DA, Ljunggren HG, Aleman S, Buggert M (2020) Robust T Cell Immunity in Convalescent Individuals with Asymptomatic or Mild COVID-19. Cell 183:13-15. doi:10.10160. cell.2020.08.017

Seow J, Graham C, Merrick B, Acors S, Steel KJA, Hemmings O, O'Brien A,Kouphou N, Pickering S, Galao R, Betancor G, Wilson HD, Signell AW, Winstone H, Kerridge K, Temperrton N, Snell L, Bisnauthsing K, Moore A, Green A, Martinez, M, Stokes B, Honey J, Izquierdo-Barras A, Arbane G, Patel A, OConnell L, O Hara G, Macmahon E, Douthwaite S, Nebbia G, Batra R, Martinez-Nunez R, Edgeworth JD, Neil SLD, Malim NH, Doores K (2020) Longitudinal evaluation and decline of antibody responses in SARS-CoV2 infection. medRxiv:20148429v1 [Preprint] [Cited 27/10/2020] Available from https://www.medrxiv.org/ content/10.1101/2020.07.09.20148429v1. https://doi.org/10.1101/2020.07.09.20148429 
It is made available under a CC-BY-NC 4.0 International license .

Vijgen L, Keyaerts E, Moes E, Thoelen I, Wollants E, Lemey P, Vandamme AM, van Ranst, M (2005) Complete genomic sequence of human coronavirus OC43: Molecular clock analysis suggests a relatively recent zoonotic coronavirus transmission event. J Virol 79: 1595-1604. doi:10.1128/JVI.79.3.1595-1604.2005

Walsh EE,Shin JH, Falsey AR (2013) Clinical Impact of Human Coronaviruses 229E and OC43 Infection in Diverse Adult Populations. J Inf Dis 208:1634-1642. 10.1093/infdis/jit393

Ward H, Cooke G, Atchison C, Whitaker M, Elliott J, Moshe M, Brown JC, Flower B, Daunt A, Ainslie K, Ashby D, Donnelly C, Riley S, Darzi A, Barclay W, Elliott P (2020) Declining prevalence of antibody positivity to SARS-CoV-2: a community study of 365,000 adults. medRxiv:.20219725v1 [Preprint][Cited 28/10/2020] Available from https://www.medrxiv.org/content/10.1101/2020.10.26.20219725v1.full.pdf

Wilder-Smith A, Teleman MD, Heng BH, Earnest A, Ling AE, Leo YL (2005) Asymptomatic SARS Coronavirus Infection among Healthcare Workers, Singapore. Emerg. Infect. Dis. 11: 1142-1145. doi: 10.3201/eid1107.041165

Woo PCY, Lau SKP, Tsoi HW, Huang Y, Poon RWS, Chu CM, Lee RA, Luk WK, Wong GKM, Wong, BHL, Cheng VCC, Tang BSF, Wu AKL, Yung RWH, Chen HL, Guan Y, Chan KH, Yuen, KY (2005) Clinical and molecular epidemiological features of coronavirus HKU1-associated community-acquired pneumonia. J. Inf. Dis. 192:1898-1907. doi:10.1086/497151

Zhang Q, Bastard P, Liu Z, Le Pen J, Moncada-Velez M, Chen J, Ogishi M, Sabli IKD, Hodeib S, Korol C, Rosain J, Bilguvar K, Ye J, Bolze A, Bigio B, Yang R, Arias AA, Zhou Q, Zhang Y, Onodi F, Korniotis S, Karpf L, Philippot Q, Chbihi M, Bonnet-Madin L, Dorgham K, Smith N, Schneider WM, Razooky BS, Hoffmann H, Michailidis E, Moens L, Han JE, Lorenzo L, Bizien L, Meade P, Neehus A, Ugurbil AC, Corneau A, Kerner G, Zhang P, Rapaport F, Seeleuthner Y, Manry J, Masson C, Schmitt Y, Schlüter A, Le Voyer T, Khan T, Li J, Fellay J, Roussel L, Shahrooei M, Alosaimi MF, Mansouri D, Al-Saud H, Al-Mulla F, Almourfi F, Al-Muhsen SZ, Alsohime F, Al Turki S, Hasanato R, van de Beek D, Biondi A, Bettini LR, D'Angio M, Bonfanti P, Imberti L, Sottini A, Paghera S, Quiros-Roldan E, Rossi C, Oler AJ, Tompkins MF, Alba C, Vandernoot I, Goffard J, Smits G, Migeotte I, Haerynck F, Soler-Palacin P, Martin-Nalda A, Colobran R, Morange P, Keles L, Çölkesen F, Ozcelik T, Yasar KK, Senoglu S, Karabela ŞN, Rodríguez-Gallego C, Novelli G, Hraiech S, Tandjaoui-Lambiotte Y, Duval X, Laouénan C, , COVID-STORM Clinicians COVID Clinicians, Imagine COVID Group, French COVID Cohort Study Group, CoV-Contact Cohort, Amsterdam UMC Covid-19 Biobank, COVID Human Genetic Effort, NIAID-USUHS/TAGC COVID Immunity Group, Snow AL, Dalgard CL, Milner JD, Vinh DC, Mogensen TH, Marr N, Spaan AN, Boisson B, Boisson-Dupuis S, Bustamante J, Puel A, Ciancanelli MJ, Meyts I, Maniatis T, Soumelis V, Amara A, Nussenzweig M, García-Sastre A, Krammer F, Pujol A, Duffy D, Lifton RP, Zhang S, Gorochov G, Béziat V, Jouanguy E, Sancho-Shimizu V, Rice CM, Su HC, Casanova J (2020) Inborn errors of type I IFN immunity in patients with life-threatening COVID-19. Science 370:eabd4570. doi:10.1126/science.abd4570

Zhou WM,Wang W,Wang HJ, Lu RJ, Tan WJ (2013) First infection by all four non-severe acute respiratory syndrome human coronaviruses takes place during childhood. BMC Inf Dis 13:433. doi:10.1186/1471-233413-433 
medRxiv preprint doi: https://doi.org/10.1101/2020.11.08.20227975; this version posted December 18, 2020. The copyright holder for this preprint (which was not certified by peer review) is the author/funder, who has granted medRxiv a license to display the preprint in perpetuity.

It is made available under a CC-BY-NC 4.0 International license .

\section{List of Tables}

1 Comparison of deaths obtained from simulation against that calculated from IFR - Eng-

land+Wales. . . . . . . . . . . . . . . . . . . . . . . . . . . . . . 14

2 Comparison of deaths obtained from simulation against that calculated from IFR - Singapore. 15

3 Median time to fatal infection (MTFI) for population at start of outbreak in the England + Wales scenario . . . . . . . . . . . . . . . . . . . . . . . . . 16

4 Remaining lifetime IFR (\%) for population at start of outbreak in the England+Wales scenario 17

5 Vaccination - E+W. Mortality rates were averaged over t=48-50. '>60 @start': vaccinating over 60s at start. '>20 @start': vaccinating over 20s at start. '>60 20\%/yr': vaccinating 20\% of over 60 s each year. '>60 40\%/yr': vaccinating $40 \%$ of over 60 s each year. . . . . . . . . 18

6 Vaccination - SG. Mortality rates were averaged over $\mathrm{t}=48-50$. '>60 @start': vaccinating over 60 s at start. '>20 @start': vaccinating over 20s at start. '>60 20\%/yr': vaccinating 20\% of over 60 s each year. '>60 40\%/yr': vaccinating $40 \%$ of over 60 s each year. . . . . . . . . . 
medRxiv preprint doi: https://doi.org/10.1101/2020.11.08.20227975; this version posted December 18, 2020. The copyright holder for this preprint (which was not certified by peer review) is the author/funder, who has granted medRxiv a license to display the preprint in perpetuity.

It is made available under a CC-BY-NC 4.0 International license.

\begin{tabular}{crrr}
\hline Age group & Simulated & Expected & Fold difference \\
\hline $0-9$ & 0 & 0 & 1.11 \\
$10-19$ & 1 & 1 & 1.03 \\
$20-29$ & 8 & 8 & 1.00 \\
$30-29$ & 28 & 28 & 1.00 \\
$40-49$ & 90 & 89 & 1.00 \\
$50-59$ & 330 & 328 & 1.00 \\
$60-69$ & 902 & 886 & 1.02 \\
$70-79$ & 2258 & 2207 & 1.02 \\
$80+$ & 4880 & 5130 & 0.95 \\
Total & 8497 & 8678 & 0.98 \\
\hline
\end{tabular}

Table 1: Comparison of deaths obtained from simulation against that calculated from IFR - England+Wales. 
medRxiv preprint doi: https://doi.org/10.1101/2020.11.08.20227975; this version posted December 18, 2020. The copyright holder for this preprint (which was not certified by peer review) is the author/funder, who has granted medRxiv a license to display the preprint in perpetuity.

It is made available under a CC-BY-NC 4.0 International license.

\begin{tabular}{crrr}
\hline Age group & Simulated & Expected & Fold difference \\
\hline $0-9$ & 0 & 0 & 0.96 \\
$10-19$ & 2 & 1 & 1.04 \\
$20-29$ & 8 & 8 & 1.04 \\
$30-29$ & 27 & 28 & 0.98 \\
$40-49$ & 97 & 92 & 1.05 \\
$50-59$ & 394 & 366 & 1.07 \\
$60-69$ & 1111 & 1012 & 1.10 \\
$70-79$ & 1663 & 1803 & 0.92 \\
$80+$ & 2746 & 3606 & 0.76 \\
Total & 6047 & 6918 & 0.87 \\
\hline
\end{tabular}

Table 2: Comparison of deaths obtained from simulation against that calculated from IFR - Singapore. 
medRxiv preprint doi: https://doi.org/10.1101/2020.11.08.20227975; this version posted December 18, 2020. The copyright holder for this preprint (which was not certified by peer review) is the author/funder, who has granted medRxiv a license to display the preprint in perpetuity.

It is made available under a CC-BY-NC 4.0 International license .

\begin{tabular}{crrrrr}
\hline Age group & Lifelong FII & $\kappa=0.025$ & $\kappa=0.05$ & $\kappa=0.10$ & $\kappa=0.20$ \\
\hline $0-9$ & 0.2 & 80.9 & 80.8 & 80.6 & 80.2 \\
$10-19$ & 0.2 & 71.1 & 71.0 & 70.8 & 70.4 \\
$20-29$ & 0.1 & 60.9 & 60.8 & 60.6 & 60.2 \\
$30-29$ & 0.1 & 50.8 & 50.8 & 50.7 & 50.3 \\
$40-49$ & 0.1 & 40.2 & 40.4 & 40.4 & 40.1 \\
$50-59$ & 0.1 & 28.7 & 29.8 & 30.2 & 30.1 \\
$60-69$ & 0.2 & 11.1 & 17.1 & 19.1 & 19.8 \\
$70-79$ & 0.2 & 0.2 & 1.7 & 6.7 & 9.4 \\
$80+$ & 0.2 & 0.2 & 0.2 & 0.2 & 0.3 \\
\hline
\end{tabular}

Table 3: Median time to fatal infection (MTFI) for population at start of outbreak in the England+Wales scenario 
medRxiv preprint doi: https://doi.org/10.1101/2020.11.08.20227975; this version posted December 18, 2020. The copyright holder for this preprint (which was not certified by peer review) is the author/funder, who has granted medRxiv a license to display the preprint in perpetuity.

It is made available under a CC-BY-NC 4.0 International license .

\begin{tabular}{crrrrr}
\hline Age group & Lifelong FII & $\kappa=0.025$ & $\kappa=0.05$ & $\kappa=0.10$ & $\kappa=0.20$ \\
\hline $0-9$ & $0.0 \%$ & $1.1 \%$ & $2.1 \%$ & $3.9 \%$ & $6.7 \%$ \\
$10-19$ & $0.0 \%$ & $1.1 \%$ & $2.1 \%$ & $3.9 \%$ & $6.7 \%$ \\
$20-29$ & $0.0 \%$ & $1.1 \%$ & $2.1 \%$ & $3.9 \%$ & $6.7 \%$ \\
$30-29$ & $0.0 \%$ & $1.1 \%$ & $2.1 \%$ & $3.9 \%$ & $6.7 \%$ \\
$40-49$ & $0.1 \%$ & $1.2 \%$ & $2.2 \%$ & $4.0 \%$ & $6.8 \%$ \\
$50-59$ & $0.2 \%$ & $1.4 \%$ & $2.4 \%$ & $4.2 \%$ & $7.1 \%$ \\
$60-69$ & $0.9 \%$ & $2.0 \%$ & $3.0 \%$ & $4.9 \%$ & $7.8 \%$ \\
$70-79$ & $2.7 \%$ & $3.8 \%$ & $4.8 \%$ & $6.5 \%$ & $9.3 \%$ \\
$80+$ & $9.7 \%$ & $10.4 \%$ & $11.1 \%$ & $12.3 \%$ & $14.3 \%$ \\
\hline
\end{tabular}

Table 4: Remaining lifetime IFR (\%) for population at start of outbreak in the England+Wales scenario 
medRxiv preprint doi: https://doi.org/10.1101/2020.11.08.20227975; this version posted December 18, 2020. The copyright holder for this preprint (which was not certified by peer review) is the author/funder, who has granted medRxiv a license to display the preprint in perpetuity.

It is made available under a CC-BY-NC 4.0 International license .

\begin{tabular}{lrrrrr}
\hline$\kappa=$ & lifelong & 0.025 & 0.05 & 0.10 & 0.20 \\
\hline Deaths after 2 years & 7753 & 7785 & 7817 & 7879 & 7996 \\
Endemic deaths (/yr) & 0 & 142 & 272 & 500 & 864 \\
Other causes (/yr) & 12919 & 12778 & 12649 & 12421 & 12059 \\
\% of annual deaths & 0.00 & 1.10 & 2.10 & 3.87 & 6.69 \\
$>60$ @start - deaths avoided & 4036 & 3974 & 3917 & 3817 & 3657 \\
$>20$ @start - deaths avoided & 4292 & 4248 & 4207 & 4135 & 4020 \\
$>6020 \% /$ yr - Endemic deaths (/yr) & 0 & 100 & 192 & 360 & 637 \\
$>6020 \% / y r$ - \% endemic deaths avoided & $\mathrm{NA}$ & 29.8 & 29.2 & 28.1 & 26.3 \\
$>6040 \% / \mathrm{yr}$ - Endemic deaths (/yr) & 0 & 72 & 141 & 266 & 480 \\
$>6040 \% / \mathrm{yr}$ - \% endemic deaths avoided & $\mathrm{NA}$ & 49.0 & 48.3 & 46.9 & 44.4 \\
\hline
\end{tabular}

Table 5: Vaccination - E+W. Mortality rates were averaged over $\mathrm{t}=48-50$. '>60 @start': vaccinating over 60 s at start. '>20 @start': vaccinating over 20s at start. '>60 20\%/yr': vaccinating $20 \%$ of over 60 s each year. '>60 40\%/yr': vaccinating $40 \%$ of over 60 s each year. 
medRxiv preprint doi: https://doi.org/10.1101/2020.11.08.20227975; this version posted December 18, 2020. The copyright holder for this preprint (which was not certified by peer review) is the author/funder, who has granted medRxiv a license to display the preprint in perpetuity.

It is made available under a CC-BY-NC 4.0 International license .

\begin{tabular}{lrrrrr}
\hline$\kappa=$ & lifelong & 0.025 & 0.05 & 0.10 & 0.20 \\
\hline Deaths after 2 years & 5574 & 5600 & 5625 & 5674 & 5767 \\
Endemic deaths (/yr) & 0 & 178 & 339 & 619 & 1057 \\
Other causes (/yr) & 13352 & 13168 & 13002 & 12711 & 12257 \\
\% of annual deaths & 0.00 & 1.33 & 2.54 & 4.65 & 7.94 \\
$>60$ @start - deaths avoided & 2773 & 2718 & 2667 & 2580 & 2443 \\
$>20$ @start - deaths avoided & 3034 & 2986 & 2943 & 2867 & 2748 \\
$>6020 \% /$ yr - Endemic deaths (/yr) & 0 & 123 & 237 & 442 & 779 \\
$>6020 \% / y r$ - \% endemic deaths avoided & $\mathrm{NA}$ & 30.7 & 29.9 & 28.6 & 26.3 \\
$>6040 \% / \mathrm{yr}$ - Endemic deaths (/yr) & 0 & 90 & 175 & 330 & 594 \\
$>6040 \% / \mathrm{yr}$ - \% endemic deaths avoided & $\mathrm{NA}$ & 49.4 & 48.4 & 46.7 & 43.8 \\
\hline
\end{tabular}

Table 6: Vaccination - SG. Mortality rates were averaged over $\mathrm{t}=48-50$. '>60 @start': vaccinating over 60s at start. '>20 @start': vaccinating over 20s at start. '>60 20\%/yr': vaccinating $20 \%$ of over 60 s each year. '>60 40\%/yr': vaccinating $40 \%$ of over 60 s each year. 
medRxiv preprint doi: https://doi.org/10.1101/2020.11.08.20227975; this version posted December 18, 2020. The copyright holder for this preprint (which was not certified by peer review) is the author/funder, who has granted medRxiv a license to display the preprint in perpetuity.

It is made available under a CC-BY-NC 4.0 International license .

\section{List of Figures}

1 Structure of ODE model . . . . . . . . . . . . . . . . . . . . . . . . . . . 21

2 Evolution of outbreak simulations. (a) The occupancy of R, V and S states over a 50 year period are displayed for both the $\mathrm{E}+\mathrm{W}$ (solid line) and $\mathrm{SG}$ (dashed line) populations. (b) Cumulative deaths are shown for the E+W (black) and SG (red) populations. (c) Number of subjects in $\mathrm{S}$ state, differentiated on whether they were from the original cohort (black) or from new births $(\mathrm{red}) . \ldots \ldots \ldots \ldots \ldots \ldots$

3 Force of infection. (a) FOI values for 0-4, 15-19 and 75+ age groups are shown for England+Wales simulation. (b) Distribution of FOI at near-equilibrium values are shown for $\mathrm{E}+\mathrm{W}$ and Singapore simulations. . . . . . . . . . . . . . . . . .

4 Effect of differing rates of immunity loss. (a) time course of S, V and R state occupancy with lifelong FII and a low $(\kappa=0.025)$ and high $(\kappa=0.2)$ rates of loss. (b) Age distribution of $\mathrm{V}$ state at varying rates of immunity loss. (c) Age distribution of S state at varying rates of immunity loss. The large spike around age 50 corresponded to births injected by the model to balance the high number dying early in the outbreak. Note that the counts at the younger ages were swelled by new births. The final bin accumulated all subjects older than 89. . . . .

$5 \quad$ Mortality vs kappa in England+Wales. (a) outbreak mortality vs time (b) mortality rate vs time. The jitter in this panel arises from the annual aging update step. . . . . . . . . . . . . 25

$6 \quad$ Mortality vs kappa in Singapore. (a) outbreak mortality vs time (b) mortality rate vs time. The jitter in this panel arises from the annual aging update step. . . . . . . . . . . . . . 26 
medRxiv preprint doi: https://doi.org/10.1101/2020.11.08.20227975; this version posted December 18, 2020. The copyright holder for this preprint (which was not certified by peer review) is the author/funder, who has granted medRxiv a license to display the preprint in perpetuity.

It is made available under a CC-BY-NC 4.0 International license .

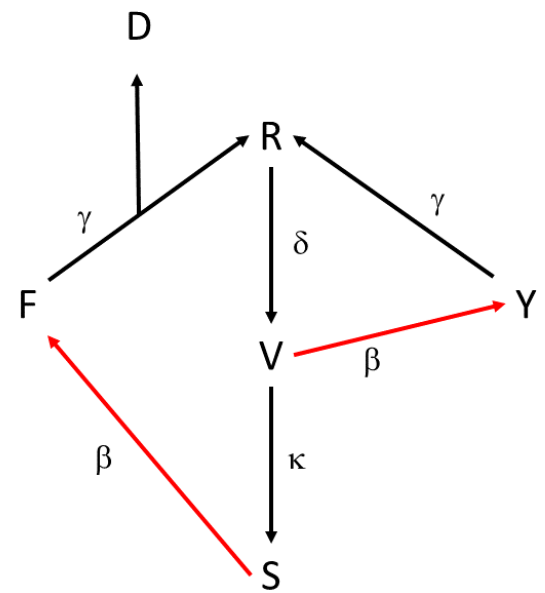

Figure 1: Structure of ODE model 
medRxiv preprint doi: https://doi.org/10.1101/2020.11.08.20227975; this version posted December 18, 2020. The copyright holder for this preprint (which was not certified by peer review) is the author/funder, who has granted medRxiv a license to display the preprint in perpetuity.

It is made available under a CC-BY-NC 4.0 International license.
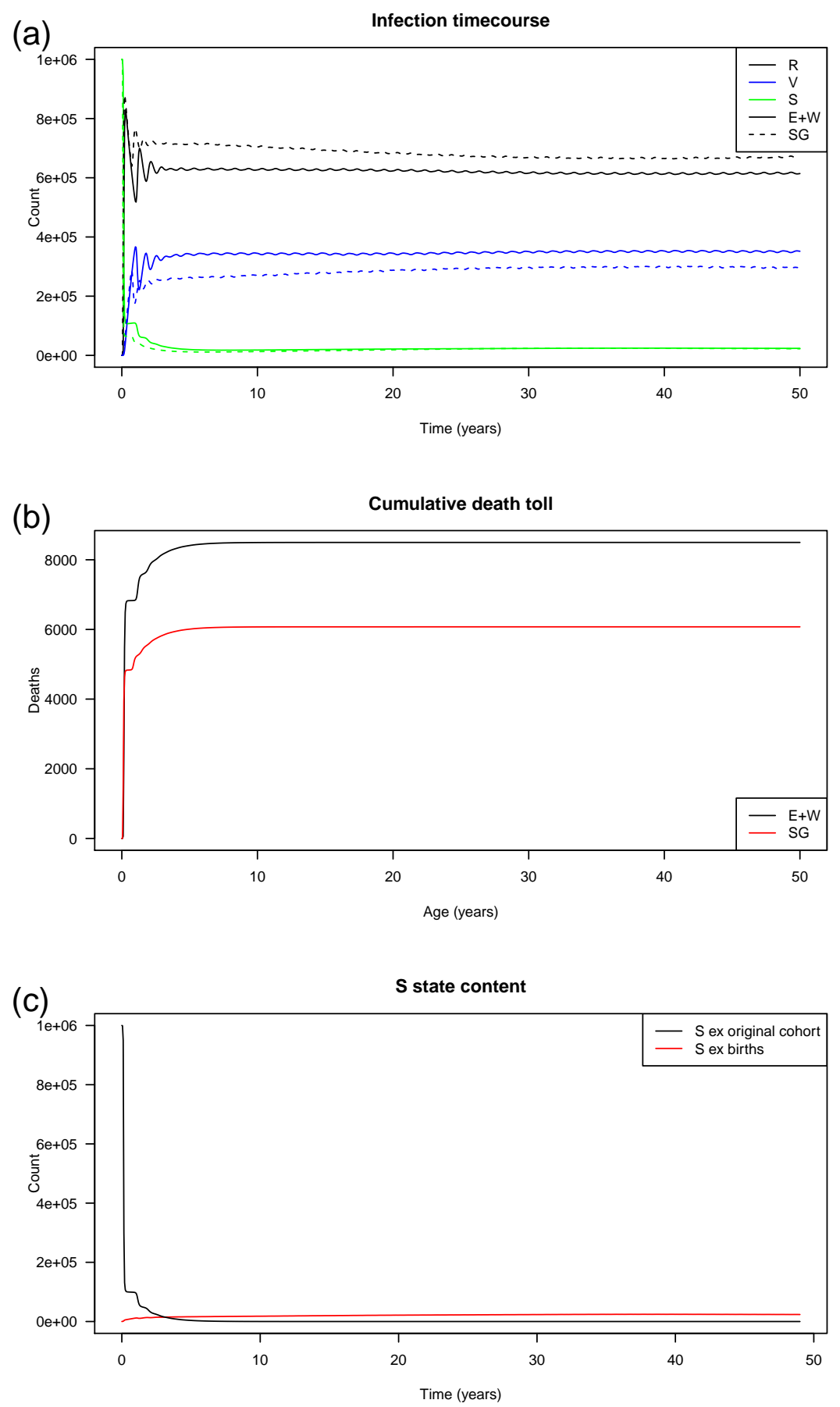

Figure 2: Evolution of outbreak simulations. (a) The occupancy of R, V and S states over a 50 year period are displayed for both the $\mathrm{E}+\mathrm{W}$ (solid line) and SG (dashed line) populations. (b) Cumulative deaths are shown for the E+W (black) and SG (red) populations. (c) Number of subjects in S state, differentiated on whether they were from the original cohort (black) or from new births (red). 
medRxiv preprint doi: https://doi.org/10.1101/2020.11.08.20227975; this version posted December 18, 2020. The copyright holder for this preprint (which was not certified by peer review) is the author/funder, who has granted medRxiv a license to display the preprint in perpetuity.

It is made available under a CC-BY-NC 4.0 International license.

(a)

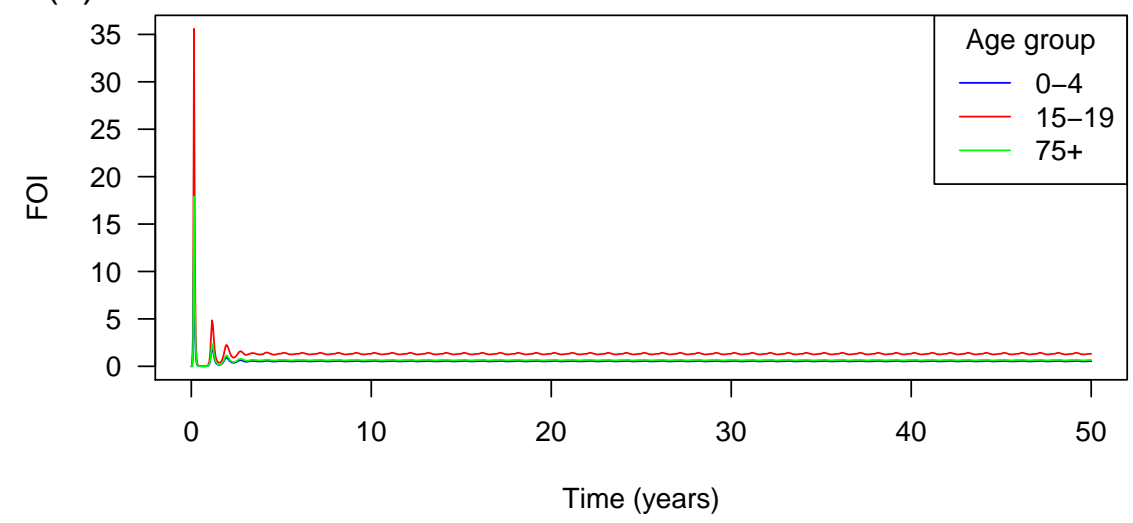

(b)

Force of infection at $\mathrm{t}=50$

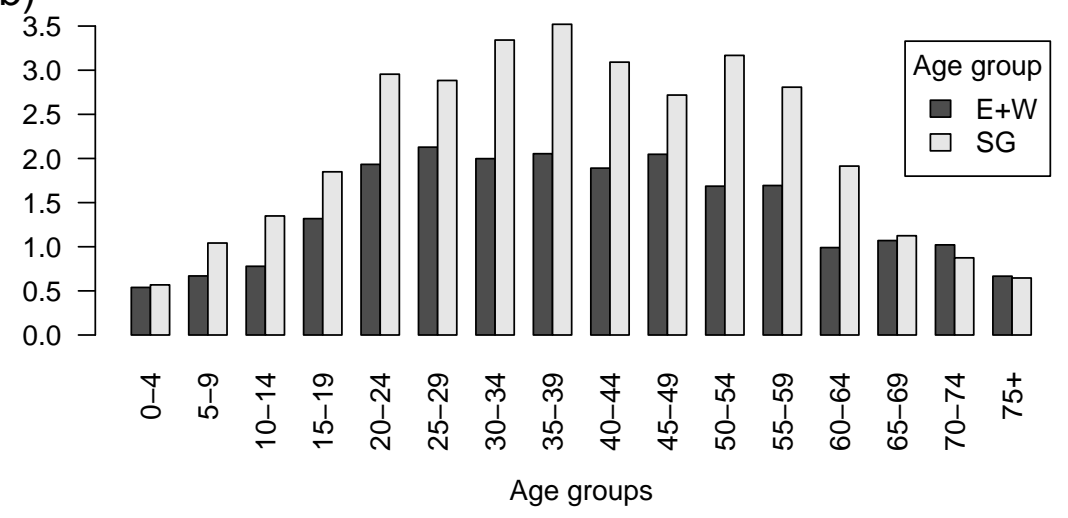

Figure 3: Force of infection. (a) FOI values for 0-4, 15-19 and 75+ age groups are shown for England + Wales simulation. (b) Distribution of FOI at near-equilibrium values are shown for $\mathrm{E}+\mathrm{W}$ and Singapore simulations. 
medRxiv preprint doi: https://doi.org/10.1101/2020.11.08.20227975; this version posted December 18, 2020. The copyright holder for this preprint (which was not certified by peer review) is the author/funder, who has granted medRxiv a license to display the preprint in perpetuity.

It is made available under a CC-BY-NC 4.0 International license.

(a)

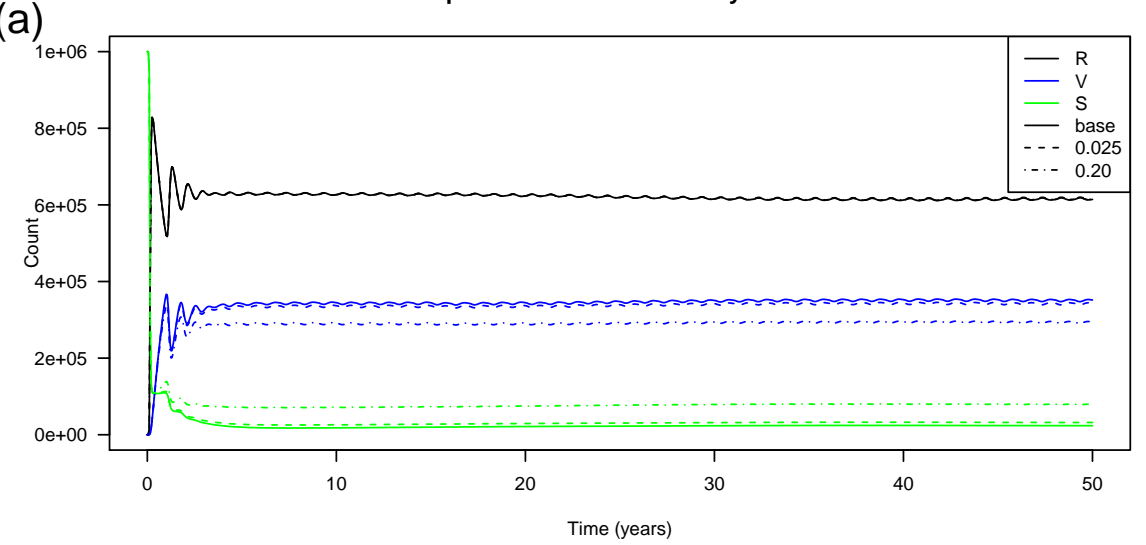

(b)

Population in zero-virus mortality loop states

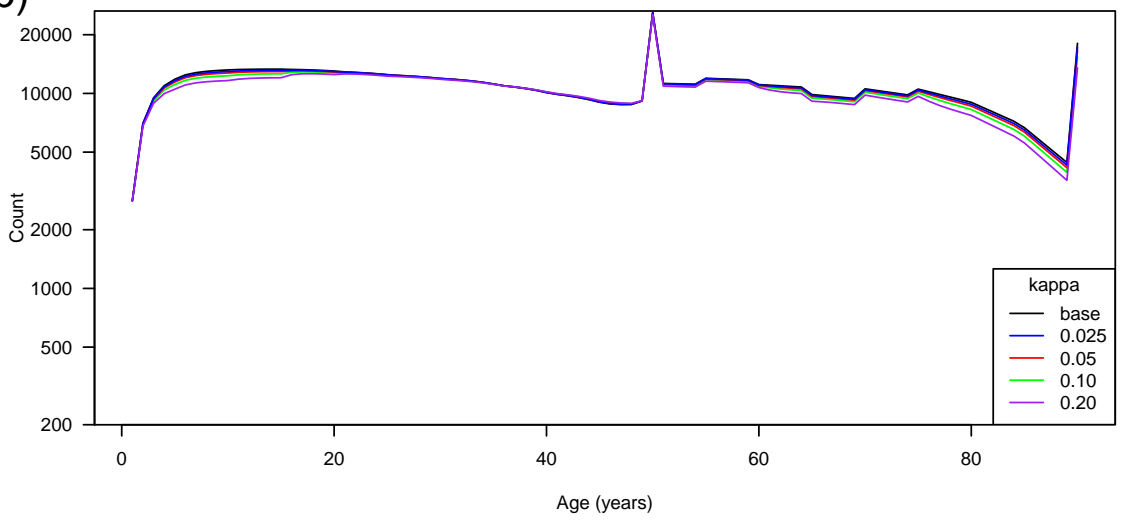

(c)

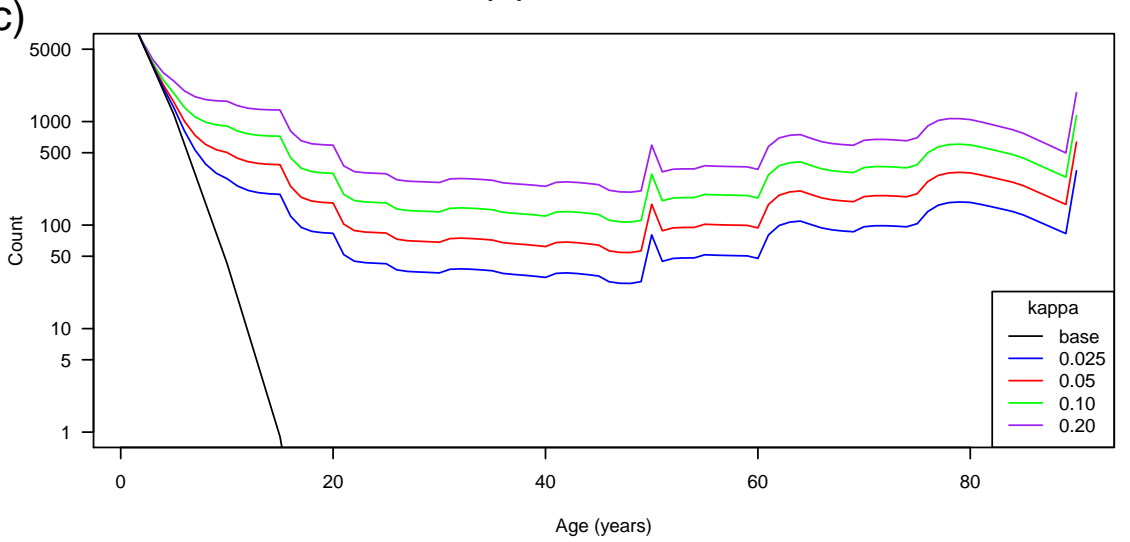

Figure 4: Effect of differing rates of immunity loss. (a) time course of S, V and R state occupancy with lifelong FII and a low $(\kappa=0.025)$ and high $(\kappa=0.2)$ rates of loss. (b) Age distribution of V state at varying rates of immunity loss. (c) Age distribution of S state at varying rates of immunity loss. The large spike around age 50 corresponded to births injected by the model to balance the high number dying early in the outbreak. Note that the counts at the younger ages were swelled by new births. The final bin accumulated all subjects older than 89 . 
medRxiv preprint doi: https://doi.org/10.1101/2020.11.08.20227975; this version posted December 18, 2020. The copyright holder for this preprint (which was not certified by peer review) is the author/funder, who has granted medRxiv a license to display the preprint in perpetuity.

It is made available under a CC-BY-NC 4.0 International license.

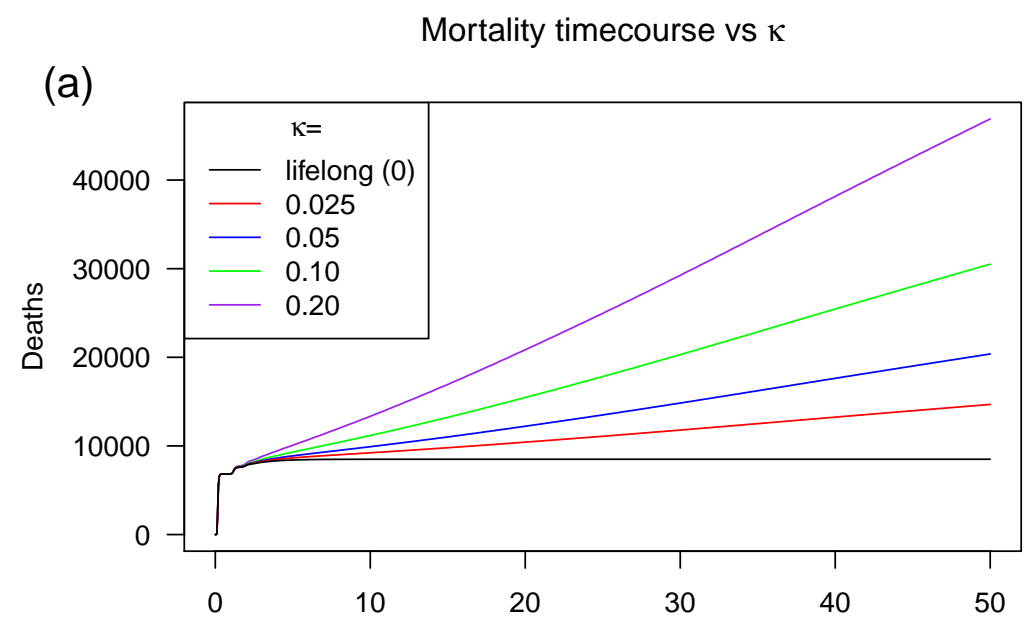

Time (years)
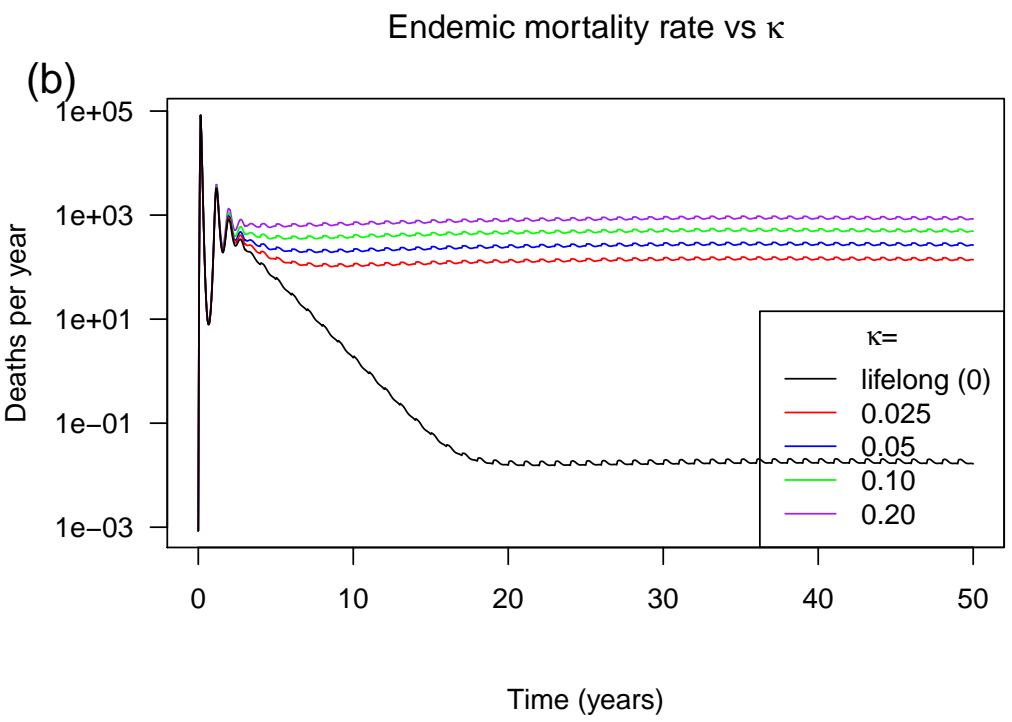

Figure 5: Mortality vs kappa in England+Wales. (a) outbreak mortality vs time (b) mortality rate vs time. The jitter in this panel arises from the annual aging update step. 
medRxiv preprint doi: https://doi.org/10.1101/2020.11.08.20227975; this version posted December 18, 2020. The copyright holder for this preprint (which was not certified by peer review) is the author/funder, who has granted medRxiv a license to display the preprint in perpetuity.

It is made available under a CC-BY-NC 4.0 International license.

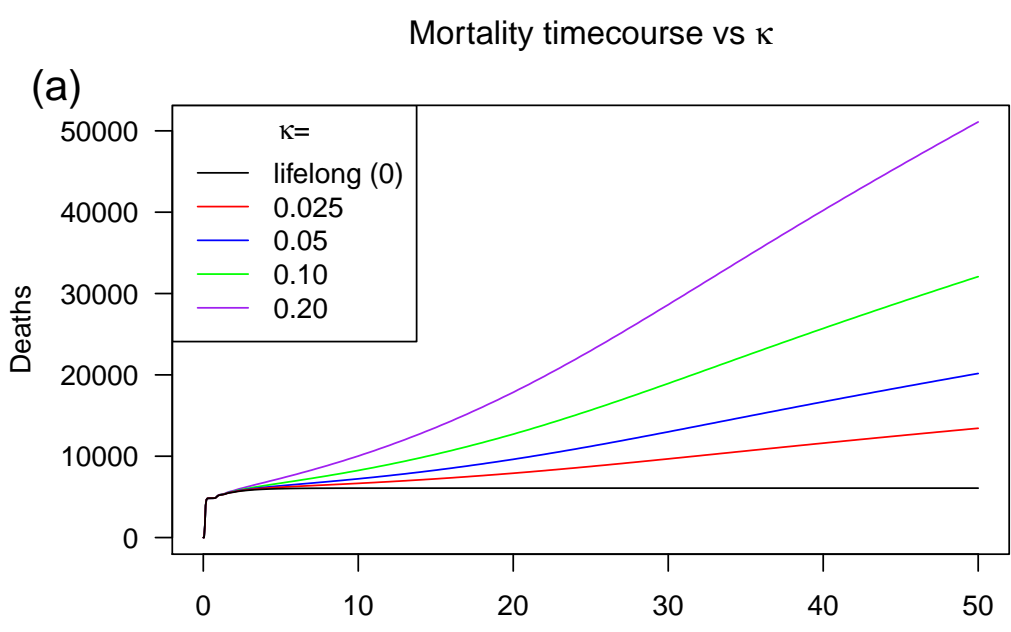

Time (years)

(b)

Endemic mortality rate vs $\kappa$

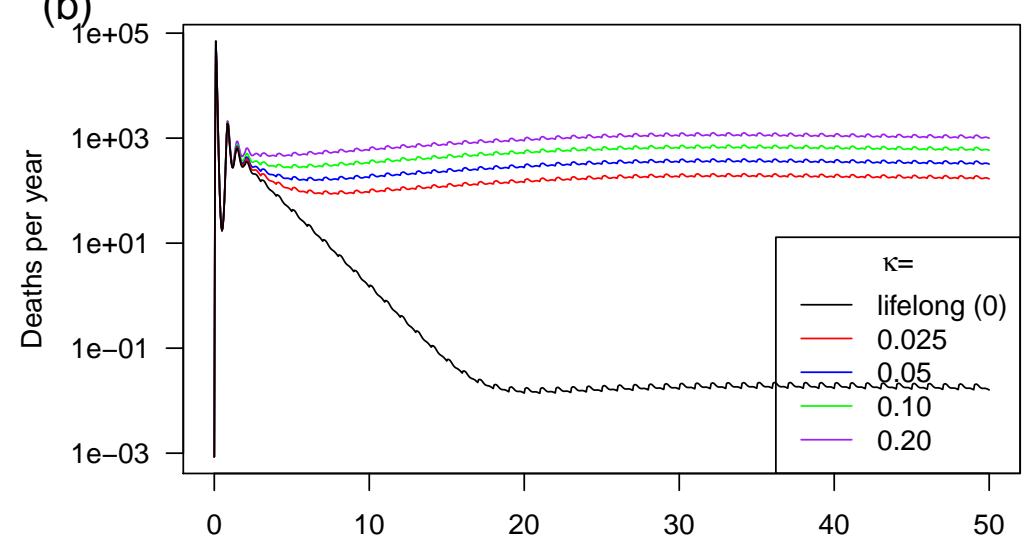

Time (years)

Figure 6: Mortality vs kappa in Singapore. (a) outbreak mortality vs time (b) mortality rate vs time. The jitter in this panel arises from the annual aging update step. 